\title{
Stapelieae (Asclepiadaceae) from South Tropical Africa: VII
}

\section{C. LEACH*}

\section{ABSTRACT}

The identity of typical Caralluma caudata N.E. Br. is discussed; two subspecies are recognized, one of which, subsp. rhodesiaca Leach, is described here, and details of their synonymy, variation and distribution are given. Two putative intergeneric hybrids, with $C$. caudata one parent, are assumed and from the evidence submitted the identity of one of these with Stapelia tarantuloides R. A. Dyer is adduced.

Caralluma caudata N.E.Br. in Fl. Trop. Afr. 4: 485 (1904); Berger, Stap. u. Klein.: 88 (1910); White \& Sloane, Stap. ed. 2, 1: 348, 3: 1155 (1937); Jacobsen. Handb. Succ. Pl. 1: 242 (1960) et Sukk. Lexikon 108 (1970). Type: Malawi (Nyasaland), Namasi (Namadzi), Cameron 25 (K!).

Chromosome number: $2 \mathrm{n}=22$.

Although the variations in the precise size and shape of the corolla and corona lobes of this showy, albeit most malodorous, species repeat the pattern found in most members of the genus, two quite distinct subspecies may be recognised. One, the typical, rare except in the Mbala (Abercorn) region, appears to be restricted mainly, if not entirely, to the northern parts of the Zambesi basin; the other seems to be distributed solely to the south of that river and extending into the Sabi and Limpopo catchment areas is possibly the most widespread and common stapeliad in Rhodesia.

The two taxa are distinguished mainly by their vegetative characteristics and are easily recognized by the colour of their stems, which in subsp. caudata are olive to dark olive-green, sometimes appearing to be brownish or purplish from the markings and crowded specklings with which they are often covered. Those of

* 157 Rhodesville Avenue, Greendale, Salisbury, Rhodesia. subsp. rhodesiaca are pale greenish grey to greyish green, usually with purplish red markings, and differ from those of the typical subspecies, perhaps even more significantly, in the length of their tapering stem teeth which are, on average, about twice as long as those of its relative. The flowers of subsp. rhodesiaca are also generally paler in colour and are often more markedly pubescent, while the spots on the disc are seldom so crowded as to appear as solid colour, as is more usual in subsp. caudata. However, these corolla characters are, like those of the corona, subject to considerable variation and flowers as dark as those of the typical subspecies are not unknown from Rhodesia. Subsp. rhodesiaca generally flowers earlier than subsp. caudata and in fewer flowered umbels, with flowers opening in a more widely spaced succession, so that it is seldom that more than two are open at a time in any one inflorescence. In the typical subspecies, on the other hand, flower development occurs more nearly simultaneously, with the result that umbels with 5-6 open flowers are by no means uncommon.

Despite their discrete distributions and although so readily distinguished from each other, it is considered that subspecific status is most appropriate for these two taxa in view of their almost identical floral characteristics.

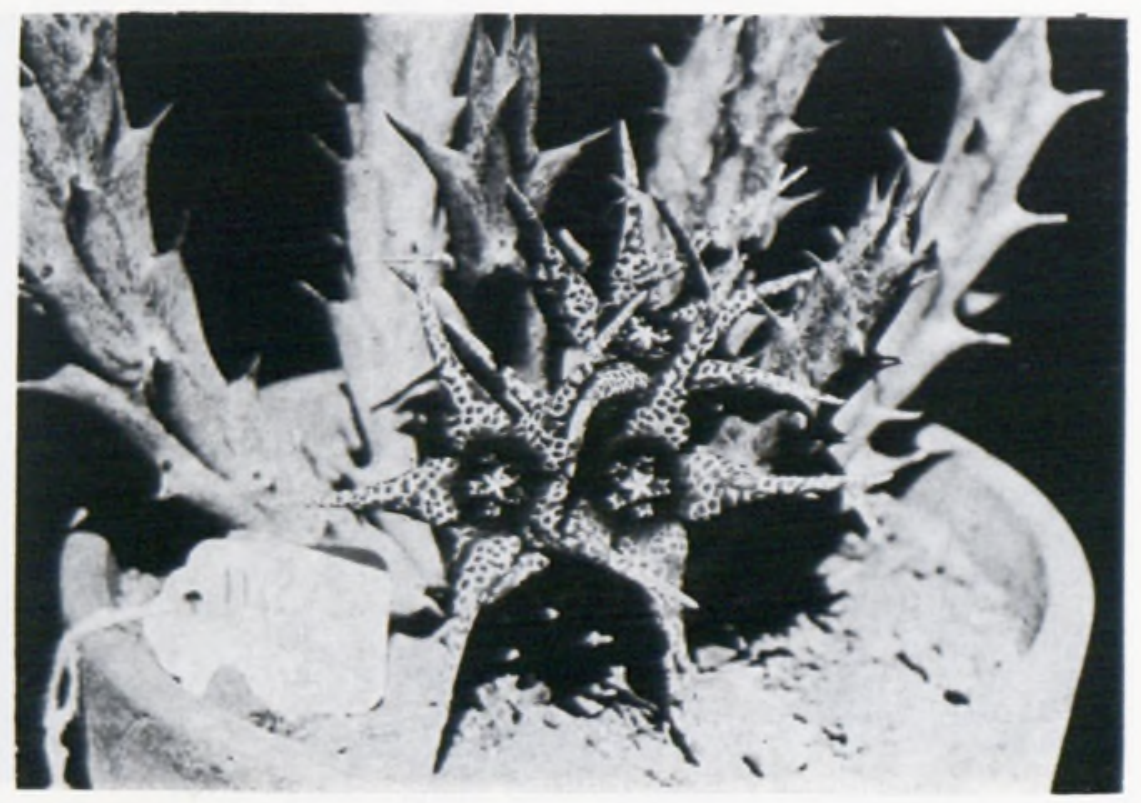

FIG. 1.-Caralluma caudata subsp. caudata. Plant from Mbala, Zambia, cult. Nelspruit (14883). 


\section{subsp. caudata}

Caralluma longecornuta Croizat ex Gomes e Sousa in Rev. Moçambique 4: 44 (1935) et 6: 20 (1936); White \& Sloane, op. cit. 1: 35 (1937), nom. nud. Type: Mozambique, Niassa Distr. Mandimba, $R$. da Torre 4 (COI! PRE!).

Caralluma praegracilis Oberm. in White \& Sloane, op. cit., 3: 1161 (1937); Luckhoff, Stap. S. Afr.: 56, 57 (1952); Jacobsen, Handb. Succ. Pl.1: 253 et Sukk. Lexikon 114 (1970), p.p. excl. distrib. Rhodesia. Type: Zululand, Nongoma, Gerstner 752

Caralluma caudata N.E. Br. var. fusca Luckhoff in White \& Sloane, Stap. ed. 2, 3: 144 (1937); Luckhoff, Stap. S. Afr. 53 (1952); Jacobsen, Handb. Succ. PI. 1 : 243 (1960) et Sukk. Lexikon 108 (1970). No type cited, locality unknown.

In the absence of material, this variety is assigned to this subspecies on the evidence of the photograph in White \& Sloane, I.c., Fig. 287, and is placed in synonymy as it is considered probably to be merely a slight colour variant caused by the spots becoming more or less confluent over the whole corolla rather than this being restricted to the disc.

Chromosome number: $2 \mathrm{n}=22$. Leach \& Brunton 10078 (SRGH).

It is perhaps unfortunate that the type specimen of $C$. caudata originated from an area where the species seems to be of such rare occurrence: since Cameron's original gathering from Namasi (modern spelling Namadzi), which lies about half way between Blantyre and Zomba, it appears from the records to have been collected only once in Malawi (Reynecke 30). Dr. Reynecke's plant appears to be a good match for the type material and is certainly identical with those from around Mbala and adjacent parts of Tanzania. It is among these latter that examples occur which appear to be identical in all respects with the plant described as $C$. praegracilis, and to which White \& Sloane l.c. referred as being common in Rhodesian garden rockeries. It seems quite possible that these cultivated plants originated from Mbala; certainly they are equally disease resistant and tolerant of heavy rainfall. It is considered that the Reverend Gerstner's specimen may well have been an escape from similarly cultivated garden plants, especially as the species appears never to have been again collected in Natal.

The specimen from Mandimba in northern Mozambique (provisionally named $C$. longecornuta by Croizat) does not, unfortunately, include stems, but the flowers appear to match those of the type, especially in respect of the " $T$ " -shaped outer coronal lobes; it is therefore, and in conformity with the distributional evidence, considered to belong here.

TANZANIA.-T4: Ufipa Distr., near Zambian borderon Mbala-Sumbawanga road, granite slope in association with Aloe mzimbana Christian, cult. Greendale \& Nelspruit, Leach \& Brunton 10078 (BM; BOL; BR; K; LISC; PRE; SRGH; ZSS); ibid. cult. PRE 15872, Morony s.n. (PRE).

ZAMBIA.-N: Mbala Distr. Nchalanga Hill near Mbala, cult. \& f. at Nelspruit, M. Richards s.n. sub Leach 13296 (K; NDO PRE; SRGH); ibid. Morony s.n. sub Plowes 3705 (K); near Mbala, cult. Nelspruit, Whellan s.n. sub Leach 12165 (BOL;

LISC); ibid. cult. SRGH, fl.. 26.iv.1972, Whellan s.n. sub Leach 14883 (SRGH); ibid. cult. SRGH 4699 G. Williamson s.n. (M; NBG).

Malawi.-C: Lilongwe, cult. PRE, fl. Apr. 1954, Reynecke 30

(PRE; SRGH); Namasi, fl. April 1899, Cameron 25 (K).

Mozambique.-N: Niassa Distr., Mandimba, f. Jan. 1937, $R$. da Torre 4 (COI; PRE).

RHODESIA.-Origin unknown, common in cult., fl. 27.ii.1958, Leach 5445 (SRGH), idem, fl, 7.iv.1960, Leach 9834 (SRGH).

subsp. rhodesiaca Leach, subsp. nov.

Caralluma chibensis Luckhoff in S. Afr. Gardening \& Country Life 25: 56 (1935). Type: Rhodesia, Chibi, Miss Jackson in Herb. Luckhoff 182.

Caralluma caudata var. chibensis (Luckhoff) Luckhoff in White \& Sloane, Stap, ed. 2, 1: 352 (1937); Luckhoff, Stap. S. Afr. 53 (1952); Jacobsen, Handb. Succ. PI. 1: 243 (1960) et Sukk. Lexikon 108 (1970). Type: as above.

Caralluma caudata var. stevensonii Oberm in White \& Sloane op. cit. 3: 1 156 (1937); Jacobsen, op. cit. 1: 243 (1960) et tom. cit. 108 (1970). Type: "near Salisbury", No. 34947 in Herb. Transv. Mus.

Caralluma caudata var, milleri Nel in White \& Sloane, op. cit. 3: 1158 (1937); Luckhoff, op. cit. 54 (1952); Huber in Prodr. Fl. S-W. Afr. 114: 13 (1967); Jacobsen, op. cit. $1: 243$ (1960) et tom. cit. 108 (1970). Type: Angola, Cubango (Okavango) River, A. H. Miller 7390 in Herb. Stellenbosch (STE†).

A subspecie typica caulibus viridi-griseis vel griseoviridibus; caulium dentibus plus minusve 2-plo longioribus; floribus plerumque pallidioribus, plus pubessentibus facile distinguenda.

TyPE: Rhodesia, S: Belingwe Distr,, Leach, E. J. \& W. Bullock 13145 (BM; BOL; BR ;K; LISC; PRE; SRGH, holo.; ZSS).

Chromosome number: $2 n=22$. Baker s.n. sub Leach 14123 (SRGH).

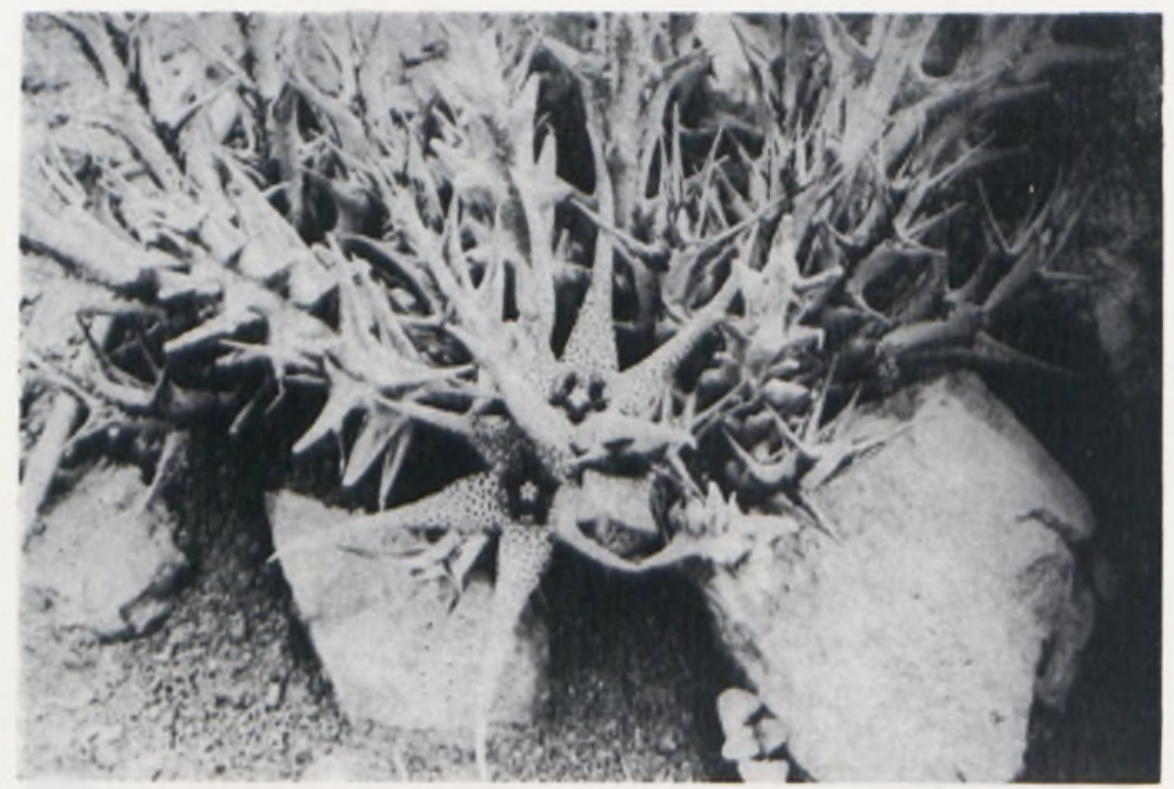

FIG. 2.-Caralluma caudata subsp. rhodesiaca. Plant from Shawanoe River, Mrewa, Rhodesia, cult. Greendale, Salisbury (49396). 
As it has not been found possible to trace any of the type specimens involved it is considered advisable to adopt an entirely new epithet for this southerly subspecies in order to ensure that no possibility of error may arise regarding its typification. The several varieties included in the synonymy were based by their respective authors on minor variations apparently in single individuals. All of these appear to fall within the range of variability to be observed in single field populations, and sometimes, particularly in respect of the shape of the inner coronal lobes, in a single individual, or even in a single flower.

ANGola.-Cuando-Cubango Distr., N. bank of Cubango (Okavango) River between Runtu and Nyangana (?Inhangana), A. H. Miller s.n. (photo of a plant in cult. PRE); ? clonotype cult. Umtali, A. H. Miller sub Plowes 2580 (SRGH). The type locality of var. milleri was originally recorded as Okavango, S. W. Africa, but it appears that this was an error since, in a letter to Mr. Plowes, Mr. Miller is most explicit that plants were found on the north bank of the river and did not occur on the south. I have been unable to find the place name Nyangana (Mr. Miller's spelling) in any maps or gazeteers available to me, but it seems certain that this is the Inhangana which is shown on one map as being $\div 93 \mathrm{~km} \mathrm{E}$ of Runtu.

S.W. Africa.-Caprivi Strip, near Katima Mulilo, cult. PRE, fl. March 1953 and Feb. 1954, Codd 7595 (BM; PRE; SRGH).

Rhodesia.-N: Gokwe Distr., Msadzi, cult. Gokwe, fl. Feb. 1964, Bingham 1107a (SRGH). Mrewa Distr., Shawanoe Riv., cult. Greendale, fl. \& fr. 1.xii.1954, Leach in SRGH 49396 (SRGH); ibid. cult. NBG, fi. 14.iv.1958, H. Hall 1146 (NBG); ibid. cult. Nelspruit, fl. Jan. 1965, Leach \& Müller 12166 (COI; K: M: NBG; SRGH: WIND). W: Matobo Distr., E. Matopos. cult. Greendale, fl. 27.ii.1958, M. Paterson sub Leach 5719 (SRGH); ibid. fi. 12.i.1958, Leach 5726 (SRGH); "Besna Kobila" rock outcrop, fl. Dec. 1956, O . B. Miller 3979 (SRGH); ibid, termite mound, fr. Sept. 1961, O. B. Miller 8019 (SRGH); Kezi, cult. Burnside, fl. 30.i.1966, fr. 7.viii.1966, W. Bullock 113/4/5 (SRGH); Gladstone Farm, cult. Burnside, fl. 30.i.1966, W. Bullock 47 (SRGH); Anglesea Farm, cult. Bulawayo Mus., fl. 30.xii.1956, M. Paterson 208 (BOL); Rowallan Park, Matopos, cult. Burnside, fl. Feb. 1964, W. Bullock 12 (K); Matopos, $67 \mathrm{~km}$ S.S.E. of Bulawayo, cult. Umtali, fl. 12.i.1972, Plowes 3836 A (PRE); Gordon Park, Matopos, fl. Feb. 1948, drawing only. Plowes (PRE). Bulawayo Distr., Burnside, fl. 15.i.1966, W. Bullock $77(\mathbf{K})$. Bulalima Mangwe Distr., Plumtree, D. A Robinson in SRGH 41636 (SRGH); ibid. cult. SRGH, fl. Feb. 1968, Drummond 8484 (SRGH). Insiza Distr., Filabusi, fl. March 1949, R. M. Davies in SRGH 22687 (SRGH); ibid., cult. NBG, fi. 13.i.1954, E. A. Schelpe in NBG 44247 (NBG). C: Gwelo Distr., Mlezu Agr. Sch. Farm, fl. 30xii.1965, Simon 580 (SRGH); ibid., fi. 5.iv.1968, Biegel 2591 (SRGH). Makoni Distr., Chiduku Res., Plowes 2465 (K). E: ?"Sabi River", without precise locality, fi. 22.i.1934, Vereker sub Eyles 7636 (K). Chipinga Distr., Chibunje, fl. 10.iii.1965 (SRGH), idem cult. Nelspruit, fl. Dec. 1965 (PRE), idem cult. Umtali, fl. 20.iii. 1967 Plowes 2476 (SRGH); Sabi Gorge (Sabi/Lundi junction) cult. Umtali, fi. $6.1 i .1965$, Plowes 2464 (BOL; K; LISC); Melsetter Distr., $35 \mathrm{~km}$ W of Melsetter, fi. 14.i.1972, Lancaster II (SRGH). S: Belingwe Distr., south of Mnene Mission, cult. Nelspruit, fl. Jan.-Feb. 1966, Leach \& Bullock 13145 (BM; BOL; BR; K; LISC; PRE; SRGH; ZSS). Chibi Distr., Tokwe Riv., cult. Greendale, fl. 21.i.1957, Leach 5467 (SR GH); “'Hippo Pools", Lundi Riv., cult. Umtali, fi. 29.ii.1968, Buckland sub Plow'es 2644 (SRGH); "Lundi", without precise locality, fl. 9.i.1934, Vereker in Herb. Eyles 7632 (K; PRE), idem cult. Salisbury, fl. 3.ii.1936 (SRGH). Gwanda Distr., $16 \mathrm{~km}$ W of Gwanda, M. Paterson 304; 309 (SRGH). Victoria Distr., Mashaba, fi. 30.xii.1955, Leach 557 I (SRGH); Mushandike Riv., cult. Nelspruit, fi. Jan. 1965, Leach 12059 (K; PRE). Shabani Distr., Shabi Riv., cult. Greendale, fl. Apr. 1960, Leach 9948 (SRGH); Ngesi Riv., fl. 26.xii.1959, Leach 9707 (SRGH); idem cult. Greendale, fl. 20.ii.1960, Leach 9766 (PRE; SRGH). Bikita Distr., Moodie's Pass, cult. Greendale, fl. 15.ii.1960, Leach 9761 (LISC).

There is greater variation in both colour and size of flower in this subspecies than in the typical; the corolla ground colour varies from yellowish cream to greenish yellow, and occasionally to dark yellow similar to that of subsp. caudata. The spots also vary considerably in size and density and in colour from light brownish red to purple or reddish violet. Some exceptionally small-flowered plants were found by Mr. Plowes near Chibunje and in the gorge near the junction of the Sabi and Lundi rivers; however, the size of the flowers increased when plants were placed in cultivation in Umtali, while similarly small flowered plants have been found at a number of localities, sometimes in association with plants displaying larger, more normally dimensioned flowers e.g. $16 \mathrm{~km} \mathrm{~W}$ of Gwanda, $M$. Paterson 304 and 309. Var. milleri was based apparently on a similar rather small-flowered specimen with corolla lobes $22 \mathrm{~mm}$ long. Cuttings, reputed to be from the type plant of this variety, were obtained from $\mathrm{Mr}$. A. H. Miller (now living in Hermanus) by Mr. Plowes; these, cultivated in Umtali, bore even smaller flowers with lobes averaging only $18 \mathrm{~mm}$ in length. There appears therefore to be no justification for taxonomic recognition of these small flowered plants as the variation from smallest to largest flowers appears to be more or less continuous and to have no distributional correlation.

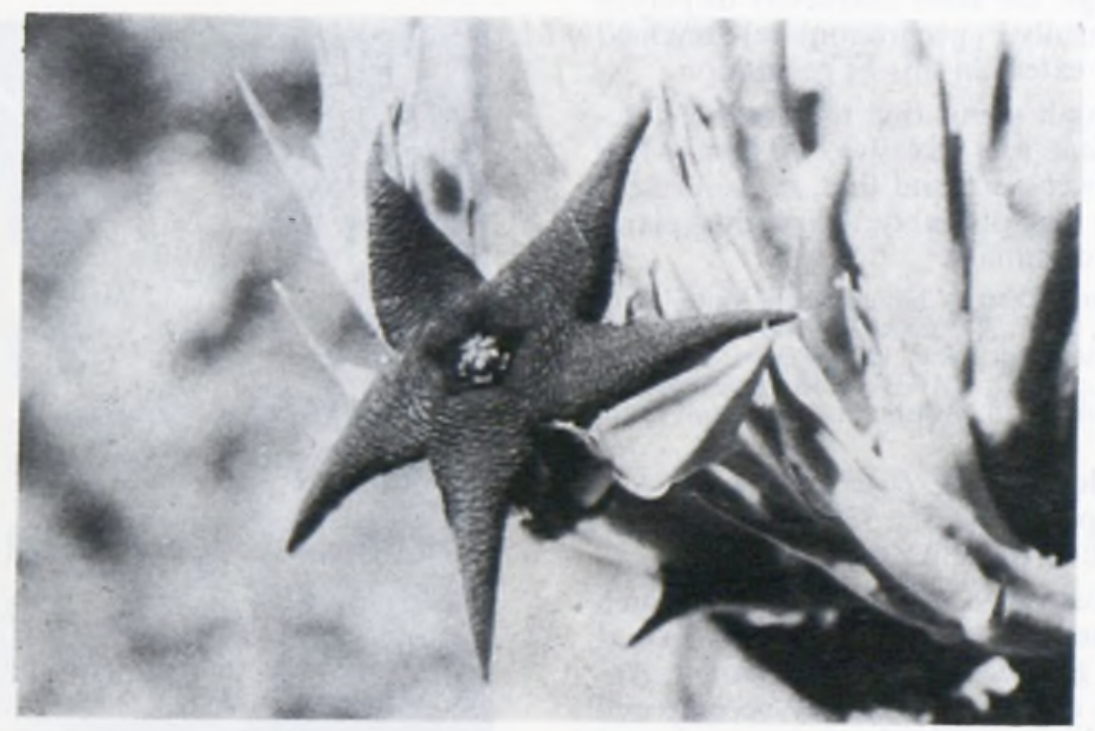

FIG. 3.-Putative hybrid: Caralluma caudata $x$ Stapelia kwebensis, assumed $F_{1}$ Plant from Chibunje, Sabi Valley, Rhodesia, cult. Nelspruit (12789). 


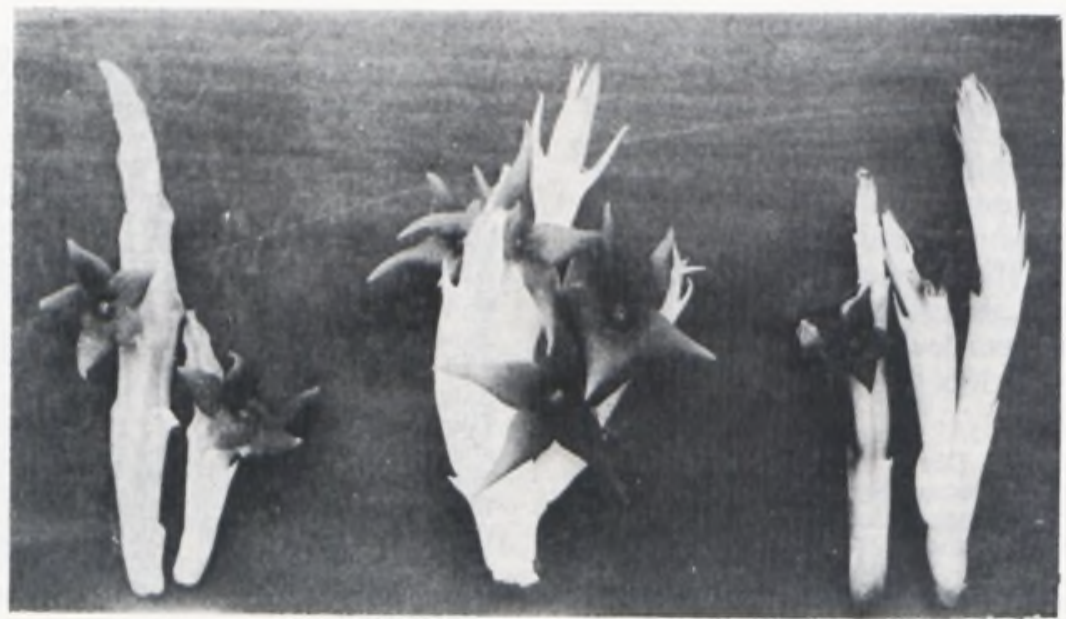

FIG. 4.--Left: Stapelia kwebensis, Dumela, Mozambique (12307); centre and right: Caralluma caudata x S. kwebensis, Chibunje, Sabi Valley; centre, assumed $F_{1}$ (12789); right, assumed $F_{2}$ (14073).

The chromosome numbers given for these two taxa are those published by Professor G. Reese in Portugaliae Acta Biologia 12: 1-23 (1971).

\section{ASSUMED INTERGENERIC HYBRIDS}

\section{N.E.Br}

Caralluma caudata N.E.Br. X Stapelia kwebensis

A plant having every indication of being of this parentage was discovered by $\mathrm{Mr}$. Plowes near Chibunje in the lower Sabi valley area of Rhodesia; this was growing amongst a number of plants of $C$. caudata subsp. rhodesiaca with, as far as could be ascertained, no $S$. $k$ webensis in the immediate vicinity, although this species is known to be not uncommon in the general area.

Cuttings from this plant, cultivated at Umtali and Nelspruit, produced rather attractive dark-coloured flowers which appeared to be nearer to those of $S$. $k$ webensis than of $C$. caudata. Plants were also raised from seed obtained from the original wild plant and flowers from these proved to be still nearer to those of $S$. kwebensis, although the stem characters displayed by the original (assumedly $F_{1}$ generation) were retained to a greater or lesser extent in this $F_{2}$ generation.

From the foregoing it seems that the floral characteristics of $C$. caudata are recessive, at least when hybridised with $S$. kwebensis, and that, in the present instance, $C$. caudata was probably the mother plant, with long stem teeth dominant.

Rhodesia.-E: Chipinga Distr., Chibunje. Sabi Valley, cult. \& fl. Umtali, Feb. 1965, D. C. H. Plowes 2477 (PRE; SRGH) idem cult. \& fl. Nelspruit Sept./Nov, 1965, Plowes, 2477 sub Leach 12789 (K; KIEL; LISC; SRGH); ibidem, seedling ex Plowes, assumed $\mathrm{F}_{2}$, cult. \& fi. Salisbury, sub Leach 14073 (SRGH).

Stapelia tarantuloides $R, A$. Dyer in Flow. Pl. Afr. 18: t.717 (1938). Type: Rhodesia, Gwanda Distr., $S$. Thompson s.n. in PRE 24162 (PRE!).

It has long been suspected that the plant on which this species was based might prove to be of hybrid origin, with Stapelia gigantea N.E.Br. one parent. Apparent confirmation of this has recently become evident in plants which have appeared spontaneously and independently in Mr. \& Mrs. Bullock's Burnside garden and in Mr. Cannell's at Rangemore, both in the Bulawayo District. No plants similar to these have ever been collected by either Mr. \& Mrs. Bullock or Mr. Cannell, although the Bullocks, in particular, are known to have made numerous trips over a number of years in an effort to rediscover plants corresponding to Sheilah Thompson's. Other searches of the general area west of Gwanda and especially along the Mwewe River by Mr. D. C. H. Plowes, the author and others have also all resulted in failure.

However, the plants which have appeared in the two gardens appear to conform in all respects with that originally described under the name $S$, tarantuloides; that these are of hybrid origin seems to be beyond dispute and since the only other species cultivated in Mr. Cannell's garden were S. gigantea and Caralluma caudata N.E.Br., it seems almost equally certain that these were the parents. The same two species were also plentifully represented in the Burnside garden and although $C$. lutea N.E.Br. (=C. lateritia N.E.Br.) was also present, both naturally and in cultivation, this is considered to be unlikely to have been involved.

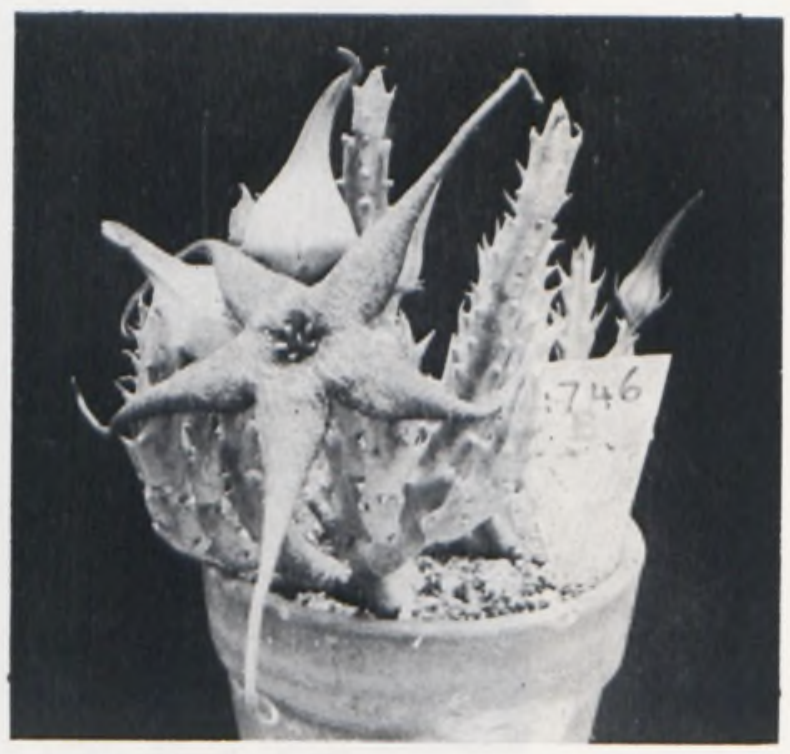

FIG. 5. - Stapelia gigantea $\times$ Caralluma caudata, assumed $F_{1}$ hybrid ( $W$. Bullock $\mathrm{GH} 2$ sub Leach $14746 \mathrm{~B}$ ). 
Of the three species, $S$. gigantea is plentiful in the Mwewe River area and $C$. caudata is not uncommon; $C$. lutea has not, on the other hand, so far been recorded.

From the foregoing it seems reasonably safe to assume that $S$. tarantuloides is a hybrid of $S$. gigantea and $C$. caudata. The assumption that $C$. caudata should be one of the parents appears to receive support from the similarity of the stems of the putative hybrid Stapelia kwebensis N.E.Br. X C. caudata, discussed elsewhere in this paper, and in which the floral characteristics of $C$. caudata also appear to be recessive and long stem teeth dominant

RHODESIA.-W: $\div 80 \mathrm{~km}$ W of Gwanda, near Mwewe Riv., in the Matopos Hilis, under protection of low thorny Acacia sp., Sheilah Thompson s.n., cult Messina, N. Transvaal, in PRE 24162 (PRE!). Bulawayo Distr., hort. Bullock, spontaneous in cultivation, fl. 1970, Bullock $G H 2$, sub Leach 14746 (PRE; SRGH), idem, with deeper tube and more attenuate corolla lobes, sub Leach 14746 A (PRE; SRGH), idem cult. Salisbury, fl. Nov. 1971, sub Leach $14746 B$ (K; KIEL); hort. Cannell; spontaneous in cultivation, fl. May 1971, Cannell 465 (PRE, SRGH).

\section{ACKNOWLEDGEMENTS}

I am much indebted to and wish to express my appreciation and thanks to:-
Mr. \& Mrs. E. J. Bullock and Mr. I. C. Cannell of Bulawayo for many live plants of the Stapelieae and for material preserved in liquid.

Dr. L. E. Codd, Director, Botanical Research Institute, Pretoria (PRE) and Mr. R. B. Drummond, Chief Botanist, Government Herbarium, Salisbury, (SRGH) for making the facilities of the respective herbaria and libraries freely available to me as well as for much technical assistance personally.

The Directors of the Department of Botany, British Museum (BM); the Bolus Herbarium, Cape Town (BOL); the Instituto Botânico Dr. Julio Henriques, Coimbra, (COI); the Centro de Botânica da Junta de Investigações do Ultramar, Lisbon (LISC); and the National Botanic Gardens, Kirstenbosch (NBG), for the loan of much valuable material.

The Director, Royal Botanic Gardens, Kew (K) for the loan of type and other material and Mr. R. M. Polhill of that institute for an extract from a letter addressed by Mr. Cameron to a Mr. W. J. Thistleton, which confirms the locality of "Namasi" and its identity with Namadzi.

Mr. D. C. H. Plowes for a great many specimens of Stapelieae in liquid as well as for live plants and especially for much information, particularly that relating to $C$. caudata var. milleri. 